\title{
A Possible Contribution of Endogenous Atrial Natriuretic Peptide to Proteinuria in Patients with Chronic Renal Failure
}

\author{
Shojiro NAOMI, Teruhisa UMEDA, Taisuke IWAOKA, \\ FUMIHIRo MIURA, YASUNORi KITAMOTO, MAHITO NAKAYAMA, AND \\ TATSuO SATO \\ Third Department of Internal Medicine, Kumamoto Univesity \\ Medical School, Kumamoto 860, Japan
}

\begin{abstract}
Plasma levels of immunoreactive atrial natriuretic peptide (IR-ANP) were measured with a specific radioimmunoassay in 19 undialysed patients with chronic renal failure. At the beginning, an extremely high level of plasma hANP $(50 \mathrm{fmol} / \mathrm{ml})$ seen in a patient was rejected with Smirnov's test and was excluded from further statistics. The plasma IR-ANP levels in these patients were significantly higher than those of 19 normal subjects matched with age and sex $(10.9 \pm 1.6 \mathrm{vs} 5.3 \pm 0.6 \mathrm{fmol} / \mathrm{ml}$, mean $\pm S E M, p<0.01)$, and positively correlated with mean blood pressure $(r=0.44, p<0.05)$ and the cardiothoracic ratio $(\mathrm{r}=0.65, \mathrm{p}<0.01)$, but did not correlate with creatinine clearance $(\mathrm{r}=-0.38$, n.s. $)$. Further, a significant correlation was observed between plasma IR-ANP and urinary protein output $(\mathrm{r}=0.47, \mathrm{p}<0.05)$. On the other hand, urinary protein output did not correlate significantly with variables such as mean blood pressure, the cardiothoracic ratio or creatinine clearance. Since it has been suggested that ANP enhances glomerular capillary permeability, increased ANP responding to volume overload in those patients may play an important role in increasing urinary protein excretion.
\end{abstract}

Key words: Atrial natriuretic peptide, Proteinuria, Chronic renal failure.

(Endocrinol Japon 38: 699-703, 1991)

\begin{abstract}
ATRIAL NATRIURETIC peptide (ANP) is a circulating hormone released from the cardiac atria in response to extracellular volume expansion [1]. Indeed, elevated plasma immunoreactive ANP (IR-ANP) levels have been demonstrated in patients with chronic renal failure [2, 3], in whom sodium and volume homeostasis are altered. Although there may be little natriuretic and diuretic response to this peptide in patients with renal failure, the role of increased plasma ANP in undialysed patients with some remaining functioning nephrons is not fully understood. The apparent increase in glomerular capillary filtration
\end{abstract}

Received: May 27, 1991

Accepted: November 22, 1991

Correspondence to: Dr. Shojiro NAOMI, Department of Internal Medicine III, Kumamoto University Medical School, 1-1-1 Honjo, Kumamoto 860, Japan. pressure caused by ANP has been thought to be a consequence of afferent arteriolar dilatation and efferent arteriolar constriction [4]. Therefore, it allowed us to speculate that the increased plasma ANP in undialysed patients with chronic renal failure might enhance glomerular capillary permeability possibly through increasing glomerular filtration pressure, and thereby contribute to augmentation of proteinuria from the remaining nephron.

In the present study, an attempt was made to investigate a pathophysiological role of endogenous plasma ANP on urinary excretion of protein in undialysed patients with chronic renal failure. Further, to ascertain what determines the plasma ANP level, the relationships between plasma IRANP and variables such as the patient's age, blood pressure, cardiothoracic ratio and endogenous 
creatinine clearance were examined.

\section{Patients and Methods}

Nineteen undialysed patients (9 males and 10 females; mean age $45.9 \mathrm{yr}$ ) with chronic renal failure with serum creatinine concentration of greater than $2 \mathrm{mg} / \mathrm{d} l$ were chosen for the present study, since urinary protein output in patients with advanced renal failure is less influenced by underlying renal disease. As a control, 19 age- and sex-matched healthy subjects (9 males and 10 females; mean age $45.1 \mathrm{yr}$ ) with normal renal function and normal blood pressure were also studied. The patients were all hospitalized for further examination of their proteinuria and diagnosed by renal biopsy as IgA glomerulonephritis in 6, rapidly progressive glomerulonephritis, diabetic nephropathy and diffuse pro- liferative lupus nephritis in 2 of each and unknown in 6 cases. In these patients, endogenous creatinine clearance ranged from 6.6 to 51.8 $\mathrm{m} / \mathrm{min}$, and the amount of urinary protein outputs varied from 0.4 to $8.8 \mathrm{~g} / \mathrm{day}$ when they were taking approximately $0.8 \mathrm{~g} / \mathrm{kg} /$ day dietary protein and 80-130 mmol sodium chloride. The mean blood pressure obtained as the sum of diastolic and one third of pulse pressure varied from 64 to $142 \mathrm{mmHg}$ when some of them were taking antihypertensive drugs. Although their cardiothoracic ratios ranged from 41 to $65 \%$, no obvious sign of decompensated cardiac failure was noticed in any case at the time of blood sampling.

The blood sample was drawn into a prechilled tube containing disodium EDTA $(1 \mathrm{mg} / \mathrm{ml})$ and aprotinine $(500 \mathrm{KIU} / \mathrm{m} l)$ on a fasted morning after 30 min supine rest. The measurement of plasma IR-ANP was performed by radioimmunoassay with a monoclonal antibody directed at the ring

Table 1. Clinical and laboratory profiles of studied patients

\begin{tabular}{|c|c|c|c|c|c|c|c|}
\hline No. & Sex/Age & $\begin{array}{c}\mathrm{MBP} \\
(\mathrm{mmHg})\end{array}$ & $\begin{array}{l}\text { CTR } \\
(\%)\end{array}$ & $\begin{array}{l}\text { Serum } \\
\text { creatinine } \\
(\mathrm{mg} / \mathrm{d} l)\end{array}$ & $\begin{array}{l}\text { Urinary } \\
\text { protein } \\
\text { (g/day) }\end{array}$ & $\begin{array}{c}\text { Plasma } \\
\text { hANP } \\
(\mathrm{fmol} / \mathrm{m} l)\end{array}$ & $\begin{array}{c}\text { Primary } \\
\text { cause }\end{array}$ \\
\hline \multicolumn{8}{|c|}{ Patient's group } \\
\hline 1. & $\mathrm{~F} / 77$ & 137 & 65 & 7.5 & 8.8 & 50.0 & 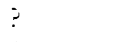 \\
\hline 2. & $F / 29$ & 92 & 47 & 4.0 & 7.1 & 7.8 & SLE \\
\hline 3. & $\mathrm{M} / 67$ & 123 & 52 & 7.5 & 7.0 & 23.3 & $\mathrm{DM}$ \\
\hline 4. & $\mathrm{M} / 22$ & 113 & 46 & 7.7 & 4.5 & 17.5 & IgAGN \\
\hline 5. & $\mathrm{~F} / 73$ & 98 & 58 & 2.9 & 4.4 & 20.6 & $?$ \\
\hline 6. & $\mathrm{M} / 63$ & 88 & 45 & 7.1 & 4.0 & 15.0 & $\mathrm{RPC} \times \mathrm{N}$ \\
\hline 7. & $\mathrm{~F} / 33$ & 88 & 46 & 2.1 & 3.7 & 4.7 & $?$ \\
\hline 8. & $\mathrm{M} / 51$ & 122 & 54 & 15.0 & 3.5 & 13.5 & $\mathrm{DM}$ \\
\hline 9. & $\mathrm{M} / 37$ & 102 & 40 & 3.1 & 2.9 & 3.9 & IgAGN \\
\hline 10. & $\mathrm{M} / 34$ & 142 & 56 & 10.0 & 2.2 & 20.0 & $?$ \\
\hline 11. & $\mathrm{M} / 27$ & 96 & 41 & 9.8 & 1.6 & 7.3 & $\operatorname{Ig} A(\mathrm{NN}$ \\
\hline 12 & $F / 44$ & 64 & 52 & 2.4 & 1.6 & 13.3 & $?$ \\
\hline 13. & $F / 55$ & 119 & 58 & 3.7 & 1.2 & 15.3 & RPGN \\
\hline 14 & $F / 44$ & 112 & 50 & 6.0 & 1.1 & 7.9 & SLE \\
\hline 15 & $F / 55$ & 118 & 53 & 7.9 & 1.0 & 4.4 & 3 \\
\hline 16 & $\mathrm{M} / 38$ & 83 & 43 & 3.8 & 0.9 & 1.3 & $\operatorname{IgAGN}$ \\
\hline 17. & $\mathrm{M} / 30$ & 93 & 43 & 2.3 & 0.7 & 1.4 & $\operatorname{IgAciN}$ \\
\hline 18. & $\mathrm{~F} / 29$ & 95 & 47 & 2.9 & 0.6 & 5.4 & $\operatorname{IgAGN}$ \\
\hline 19. & $\mathrm{~F} / 71$ & 100 & 54 & 8.4 & 0.4 & 13.5 & 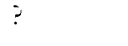 \\
\hline Mean & 45.9 & $104.5 *$ & 50.0 & $6.0 \%$ & 3.0 & $13.0 *$ & \\
\hline \pm SEM & 3.9 & 4.5 & 1.5 & 0.8 & 0.6 & 2.6 & \\
\hline \multicolumn{8}{|c|}{ Control subjects $(\mathrm{n}=19, \mathrm{~F} / \mathrm{M}=10 / 9)$} \\
\hline Mean & 45.1 & 89.4 & & 0.9 & & 5.3 & \\
\hline \pm SEM & 3.9 & 2.9 & & 0.1 & & 0.6 & \\
\hline
\end{tabular}

* $p<0.01$ us control subjects. SLE denotes systemic lupus erythematosus; DM denotes diabetes mellitus; IgAGN denotes IgA glomerulonephritis; RPGN denotes rapidly progressive glomerulonephritis. 
portion of human ANP [5]. The urinary protein concentration was measured by the pyrogallol-Red method [6]. Results were expressed as the mean \pm SEM. The significance of difference was estimated by Student's $t$ test for unpaired data. Linear regression analysis was done by means of the method of least squares. $\mathrm{P}$ values below 0.05 were considered significant.

\section{Results}

Clinical and laboratory data for patients and normal control subjects are summarised in Table 1. As shown in Table 1, an outlying level of plasma hANP $(50 \mathrm{fmol} / \mathrm{ml})$ occurred in a patient who was the oldest and had the biggest CTR, both of which could be reasons for explaining such a high level. With Smirnov's test, the extremely high level was rejected, and was excluded from further statistics. Levels of mean blood pressure in patients with chronic renal failure and in normal subjects were

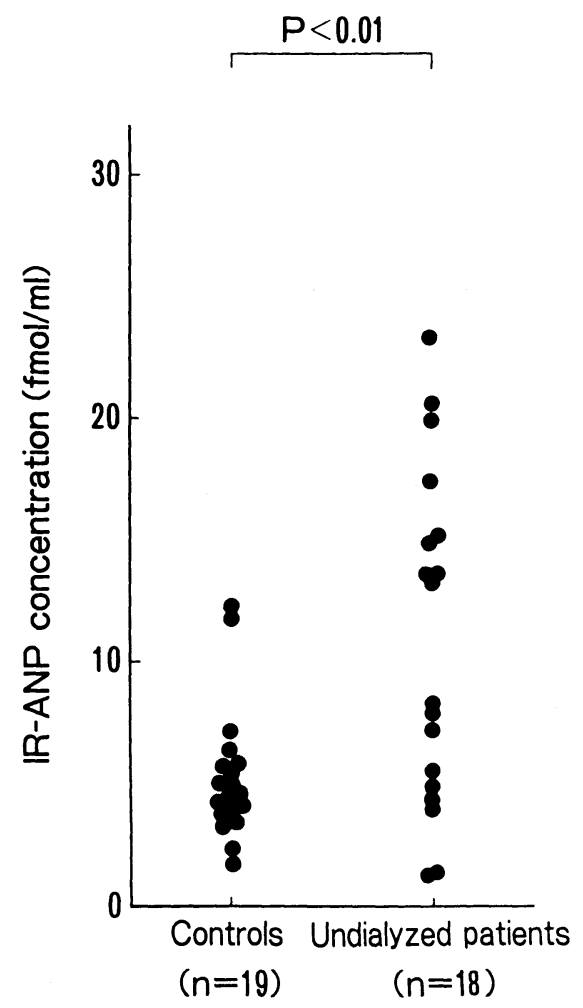

Fig. 1. Individual levels of plasma IRANP in 18 patients with chronic renal failure before dialysis and in 19 age and sex matched control subjects.

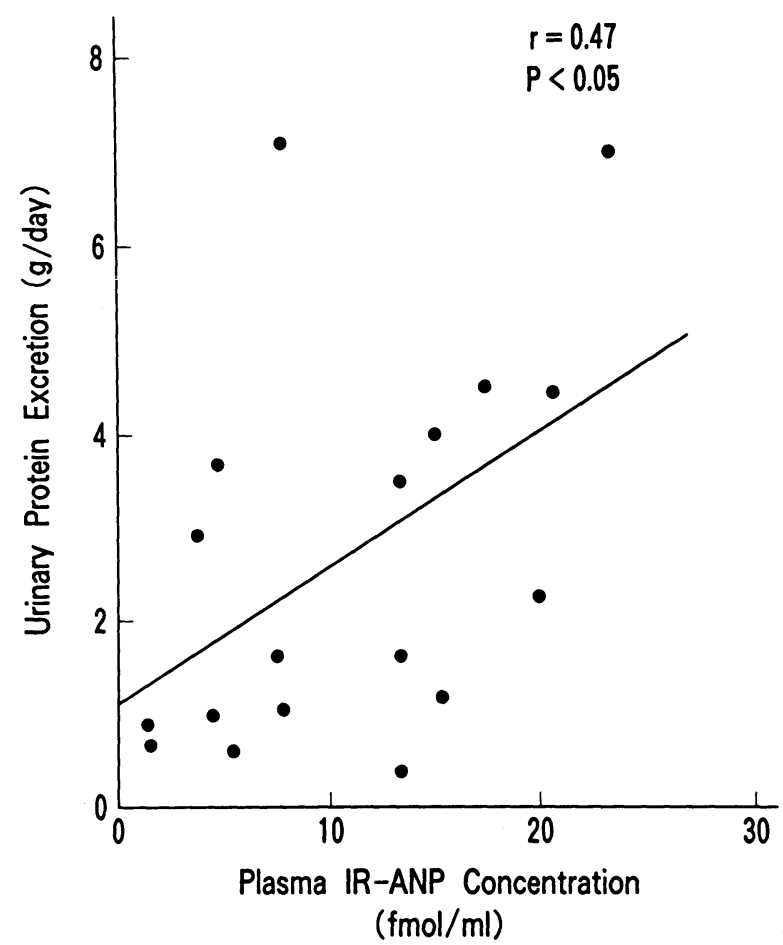

Fig. 2. Correlation between plasma IR-ANP concentration and urinary protein excretion in 18 undialysed patients with chronic renal failure.

$102.7 \pm 4.3$ and $89.4 \pm 2.9 \mathrm{mmHg}(\mathrm{p}<0.01)$, respectively. As shown in Fig. 1, plasma IR-ANP levels in these patients were significantly higher than those of the controls $(10.9 \pm 1.6$ vs $5.3 \pm 0.6 \mathrm{fmol} / \mathrm{ml}$, $\mathrm{p}<0.01$ ). In patients' group, the plasma concentration of IR-ANP correlated significantly with the cardiothoracic ratio $(\mathrm{r}=0.65, \mathrm{p}<0.01)$, mean blood pressure $(\mathrm{r}=0.44, \mathrm{p}<0.05)$ and age $(\mathrm{r}=0.51$, $\mathrm{p}<0.05)$, but did not correlate with creatinine clearance $(r=-0.38$, n.s.). Furthermore, a significant positive correlation $(r=0.47,<0.05)$ between the plasma concentration of IR-ANP and urinary protein output was observed (Fig. 2). On the other hand, the urinary protein output did not correlate with the mean blood pressure $(\mathrm{r}=0.21$, n.s.), creatinine clearance $(\mathrm{r}=-0.19$, n.s. $)$ or cardiothoracic ratio $(\mathrm{r}=0.02$, n.s.). In normal control subjects, however, the plasma concentration of IR-ANP correlated only with age $(\mathrm{r}=0.54$, $\mathrm{p}<0.02)$.

\section{Discussion}

In the present study, the elevated plasma level 
of IR-ANP was observed in patients with chronic renal failure not taking hemodialysis therapy as previously reported [3]. Although the pathophysiological significance of the elevated ANP in these patients is still unclear, it is possible that high plasma ANP could increase the intra-glomerular capillary filtration pressure and concomitantly the permeability of the capillary wall to some of the protein in the remaining functioning nephrons, and thereby enhance urinary protein excretion, as previously suggested [7]. To our knowledge, however, this is the first report that demonstrates a positive correlation between the plasma level of endogenous ANP and urinary protein output in patients with chronic renal failure.

A recent study [8] has suggested that ANP mediates the glomerular hyperfiltration in experimental diabetic rats, in which the hyperfiltration is reversed by infusion of ANP specific antiserum. However, the interrelationship among ANP, glomerular hyperfiltration and proteinuria was not discussed. Thereafter, McMurry et al. [9] demonstrated that an infusion of a pharmacological dose of ANP increased urinary albumin excretion in normal subjects, where they assumed that the rise in urinary albumin excretion was not due to inhibition of the tubular reabsorption of albumin but due to enhanced glomerular permeability, since ANP infusion did not affect excretion of $\beta_{2}$-microglobulin, which was thought to be freely filtered in the glomerulus but reabsorbed $99.9 \%$ along the proximal tubules. Furthermore, Zietse $e t$ al. [10] revealed that in patients with nephrotic syndrome who had only moderate impairment of renal function, a low dose of ANP infusion raised urinary albumin excretion. They therefore assumed that endogenous ANP might have a similar effect on such patients, although they failed to mention the relationship between urinary albumin excretion and basal plasma ANP level. Similarly, Ishii et al. [11] demonstrated a rise in urinary protein excretion during low dose ANP infusion for 20 patients with primary glomerular disease with moderate renal dysfunction. They also recognized an positive correlation between proteinuria and basal plasma ANP level $(r=0.51$, $\mathrm{p}<0.05$ ), which was comparable with our results. On the other hand, Hisanaga et al. [12] did not find an increase in plasma ANP in 9 nephrotic patients without apparent renal impairment, and also failed to demonstrate a significant correlation between proteinuria and basal plasma ANP level in the patients, although they found a positive effect of infused ANP on proteinuria. An obvious candidate for explaining the discrepancy is sample preparation. While we employed an extraction method, Hisanaga et al. employed a direct method, in which the result is often misleading with non-specific interference. Another candidate is the degree of renal impairment. While serum creatinine levels in all our patients are above $2 \mathrm{mg} / \mathrm{d} l$, those in their patients are below $2 \mathrm{mg} / \mathrm{d} l$. In the latter case, the underlying renal disease would strongly affect the production of urinary protein excretion.

In the present study, the plasma IR-ANP concentration positively correlated with mean blood pressure and the cardiothoracic ratio in undialysed patients with chronic renal failure, as reported previously [2]. These results support the current viewpoint that atrial distention, caused by volume expansion, is the basis for high ANP levels in chronic renal failure. What happens to ANP catabolism in renal failure? For example, could the elevated ANP levels be due to a reduction in renal degradation rather than increased secretion? This idea seems unlikely because the correlation between plasma IR-ANP and creatinine clearance is rather poor $(\mathrm{r}=-0.26)$. One might also consider the opposite hypothesis from the one which we advance, namely that more severe proteinuria is associated with greater sodium retention which in turn produces more atrial distention and higher ANP levels. However, this idea seems unlikely, since the correlation between urinary protein output and variables such as cardiothoracic ratio or mean blood pressure was not significant. Although further studies are clearly needed, the highly significant correlation between plasma IRANP and urinary protein output in patients with chronic renal failure can provide additional important evidence to assist in interpreting the pathophysiological role of plasma ANP.

In conclusion, the increased circulating ANP is likely to compensate for blood volume expansion in patients with renal failure and thereby protect them from congestive heart failure, while it may raise glomerular capillary permeability by increasing glomerular filtration pressure, and thus contribute to increased urinary protein excretion. 


\section{References}

1. Lang RE, Tholken H, Ganten D, Luft FC, Ruskoaho H, Unger TH (1985) Atrial natriuretic factor-circulating hormone stimulated by volume loading. Nature 314: 264-266.

2. Hasegawa $K$, Matsushita $Y$, Inoue $T$, Morii $H$, Ishibashi M, Yamaji T (1986) Plasma levels of atrial natriuretic peptide in patients with chronic renal failure. J Clin Endocrinol Metab 63: 819-822.

3. Kojima S, Inoue I, Hirata Y, Kimura G, Saito F, Kawano Y, Satani M, Ito K, Omae T (1987) Plasma concentration of immunoreactive atrial natriuretic peptide in patients on hemodialysis. Nephron 46: $45-48$.

4. Marin-Grez M, Fleming JT, Steinhausen M (1986) Atrial natriuretic peptide causes pre-glomerular vasoconstriction in rat kidney. Nature 324: 473-476.

5. Naomi S, Umeda T, Iwaoka T, Miura F, Ohno M, Sasaki M, Oishi S, Sato T, Takatsu K (1988) A sensitive radioimmunoassay of human atrial natriuretic polypeptide using monoclonal antibody recognizing human form ring structure. Life Sci 43: 761-768.

6. Fuguta Y, Mori I, Kitano B (1983) Color reaction between pyrogallol re-molybdenum (VI) complex and protein. Bunseki Kagaku 32: E379-E386 (In Japanese).
7. Brenner BM, Deen WM, Robertson CR (1976) Glomerular filtration. In: Brenner BM, Rector FC $\mathrm{Jr}$ (eds) The Kidney. Philadelphia, Saunders, 251-271.

8. Ortola FV, Ballermann B, Anderson S, Mendez RE, Brenner BM (1987) Elevated plasma atrial natriuretic peptide levels in diabetic rats: potential mediator of hyperfiltration. J Clin Invest 80: $670-674$.

9. McMurry J, Seidelin PH, Howey JEA, Balfour DJ, Struthers AD (1988) The effect of atrial natriuretic factor on urinary albumin and $\beta_{2}$-microglobulin excretion in man. J Hypertens 6: 783-786.

10. Zietse R, Schalekamp MA (1988) Effect of synthetic human atrial natriuretic peptide (102-126) in nephrotic syndrome. Kidney Int 34: 717-724.

11. Ishii $M$, Hirata $Y$, Sugimoto $T$, Matsuoka $H$, Kimura K, Ishimitsu T, Fukui K, Sugimoto T, Kurosawa Y, Kiyose H, Kangawa K, Matsuo H (1989) Effect of $\alpha$-human atrial natriuretic peptide on proteinuria in patients with primary glomerular diseases. Clin Sci 77: 643-650.

12. Hisanaga S, Yamamoto Y, Kida O, Kato J, Fujimoto S, Tanaka K (1989) Plasma concentration and renal effect of human atrial natriuretic peptide in nephrotic syndrome. Jpn J Nephrol 31: $661-669$. 